\title{
Identification of new business models in micro and small enterprises in the energy sector
}

\author{
Edyta Ropuszyńska-Surma \\ Wroclaw University of Science and Technology
}

Magdalena Węglarz (iD

Wroclaw University of Science and Technology

\section{Introduction}

The aim of the article is the initial identification of new business models among micro and small enterprises operating in the energy sector in Poland. The authors focused on micro and small enterprises which make products and deliver services including energy efficiency, energy production on the microscale, and energy savings. These enterprises very often operate within a cooperation network, which could influence their business models. The initial study was conducted by means of a direct survey answered by thirty businesses in November 2019. This study is a part of comprehensive research conducted at the Wrocław University of Science and Technology by a research team consisting of Szalbierz, Kubiński and the authors of this paper. The research in this paper is a preliminary study to major future research aiming to identify and classify new business models in the Polish energy sector. The results cannot be generalized because the initial research was done on too small a sample, but they are a good starting point for the next stage in our research.

The term business model (BM) has been widely known and used for over 60 years. Numerous analyses of business models in various industries have been conducted in the literature; however, only a few papers have concerned the energy sector. In the case of the Polish energy sector, only a few research ${ }^{1}$ projects analyzing business models can be found. The subject of the research in both cases was

$1 \quad$ E.g.: B. Nogalski, A. Szpitter, J. Brzóska, Modele i strategie biznesu w obszarze dystrybucji energii elektrycznej w Polsce, Wydawnictwo Uniwersytetu Gdańskiego, Gdańsk 2017; 
energy companies. There is no research investigating micro and small enterprises, whose activities concern energy efficiency, energy savings or energy production on the microscale.

The energy sector is a key sector in the national and EU economies due to its important role in economic prosperity and its major environmental impact. Recently, three key developments have transformed the energy sector in many countries: clean energy transition, market liberalization, and digitization. These developments have enabled new BMs in the regulatory landscape. In Europe in particular (a forerunner in both clean energy transition and market liberalization), new players have entered the markets, and existing electricity supply companies have been restructured as new business models have emerged. Additionally, a general technological transformation (called digitization) has occurred, with new technology allowing analog processes and information to be transformed into digital processes, and, in specific cases, opening up new possibilities to reach the aim of sustainability and liberalized markets efficiently. Outstanding examples in the energy sector include smart grid infrastructures, virtual power plants, renewable energy source integration, connected devices, and technologies to increase demand flexibility ${ }^{2}$.

Thus, new BMs have emerged, many of which combine digitization with contributions to the sustainable transformation of the energy sector in the liberalized environment ${ }^{3}$. In this context, new means that the energy transition and/or digitization enabled the BM, which appeared within the timeframe 2000 to 2019. The new BM contributes renewable energy or products that improve energy efficiency, reduces consumption, and/or provides social and environmental benefits ${ }^{4}$.

In the ongoing research the authors of this paper have aimed to answer the following research questions: (1) "What are the BMs in the Polish microscale energy sector?", (2) "What are the directions of the BMs' change in the context of the cooperation network?".

E. Ropuszyńska-Surma, M. Węglarz, A virtual power plant as a cooperation network, "Marketing and Management of Innovations" 2018, no. 4, pp. 136-149.

2 IEA, Digitalization and Energy, IEA, Paris 2017, https://www.iea.org/reports/digitalisationand-energy (dostęp: 4.09.2020).

3 N.M.P. Bocken et al., A literature and practice review to develop sustainable business model archetypes, "Journal of Cleaner Production” 2014, no. 65, pp. 42-56.

4 M. Richter, Business model innovation for sustainable energy: German utilities and renewable energy, "Energy Policy" 2013, no. 62, pp. 1226-1237. 


\section{Literature review}

\section{Business Models}

Since Bellman, Clark, Malcolm, Craft, and Ricciardi (1957) introduced the term business model, the BM has become a kind of simplified and aggregated representation of the essential activities of a company. Numerous papers confirm the importance of BMs in practice because they are related to ensuring and growing competitive advantage. In general, there is no one common definition of BM. Definitions of BMs differ, depending on the three basic perspectives of technology, organization and strategy. Until 2002, the most popular were technologically-oriented BMs. The importance of the strategy-oriented concept increased after 2002; however, only after 2005 was the concept of organization-oriented $\mathrm{BM}$ formulated. In recent years, an increasingly holistic approach to defining the BM can be observed. A comprehensive analysis of different BMs and their components was conducted by Wirtz et al. ${ }^{5}$ and Shafer et al. ${ }^{6}$

At the early stages of development of the technology-oriented concept, the authors identified the BM as a small part of a company, but later they increasingly started to perceive the BM as a representation of the company. Special importance is placed on the architecture of the flow of the products, services, information, and benefits (including cash) generated by the individual entities included in the model ${ }^{7}$. According to Afuah and $\mathrm{Tucci}^{8}$, the BM is perceived as a method for the increase and exploitation of a company's resources for preparing new products or services for customers, in order to obtain added value (expanding the competitive advantage or increasing profitability). Amit and Zott ${ }^{9}$ claimed that the model is a set of actions that should be taken by a company, the relation between them, and the entities responsible for the different activities.

5 B.W. Wirtz et al., Business Models: Origin, Development and Future Research Perspectives, "Long Range Planning" 2016, no. 49, pp. 36-54.

6 S.M. Shafer, H.J. Smith, J. Linder, The power of business models, "Business Horizons" 2005, vol. 48(3), pp. 199-207.

$7 \quad$ P. Timmers, Business models for electronic markets, "Electronic Markets" 1998, vol. 8, no. 2, pp. 3-8; P. Weill, M.R. Vitale, Place to Space - Migrating to e-Business Models, Harvard Business School Publishing Corporation, Boston 2001.

8 A. Afuah, C.L. Tucci, Internet Business Models and Strategies, McGraw-Hill/Irwin, New York 2003.

9 R. Amit, C. Zott, Value creation in E-business, "Strategic Management Journal" 2001, vol. 22(6/7), pp. 493-520. 
From the organization-oriented perspective ${ }^{10}$, the $\mathrm{BM}$ is seen as a tool for the $\mathrm{ab}$ straction of the entire company as a kind of a system that solves problems of strategy for the business, such as identifying the customer, recognizing their needs, delivering satisfaction, and changing value into cash. The concept focuses on the cause and effect relationships and on the reasons for value creation. The fundamental elements of the model ${ }^{11}$ are customer segments, value proposition, channels, customer relations, revenue streams, cost structure and key resources, activities and partners.

The authors, who have conducted their research in strategic management ${ }^{12}$, see the $\mathrm{BM}$ as a highly abstract tool which shows a picture of a company's competitive conditions. The key concept is that the BM is a direct result of a strategy but is not a strategy in itself. Besides, a strategic BM is defined by strategic resources, relations with buyers and the value chain. A BM can be seen as a "story" that explains how the company operates and what is especially relevant for its success ${ }^{13}$. Another opinion is that the model is perceived as a list of functions, such as formulating a competitive strategy and a value chain structure, estimating the cost structure and potential profit, and describing the position of the company ${ }^{14}$. Moreover, the model could be described by the manner in which the company delivers value to customers, encourages customers to pay for this value, and converts those payments into profit ${ }^{15}$. A more extensive review of BM definitions is given by Brzóska ${ }^{16}$, Nogalski, Spitter, and Brzóska17.

\section{Business models in the energy sector}

Only a small number of the BMs analyzed concern the energy sector, alongside a broad range of other industries. Hence, important specifics of the sector, such as clean energy transition, liberalization and digitization, are very rarely taken into account.

10 C. Baden-Fuller, S. Haefliger, Business Models and Technological Innovation, "Long Range Planning" 2013, vol. 46(6), pp. 419-426.

11 A. Osterwalder, Y. Pigneur, Business Model Generation, Wiley \& Sons, New Jersey 2010.

12 G. Hamel, Leading the Revolution, Harvard Business School Press, Boston 2000.

13 J. Magretta, Why business models matter, "Harvard Business Review" 2002, vol. 80(5), pp. 86-92.

$14 \mathrm{H}$. Chesbrough, R.S. Rosenbloom, The role of the business model in capturing value from innovation: evidence from Xerox Corporation's technology spin-off companies, "Industrial and Corporate Change" 2002, vol. 11(3), pp. 529-555.

15 D.J. Teece, Business models, business strategy and innovation, "Long Range Planning" 2010, no. 43, pp. 172-194.

16 J. Brzóska, Innowacje jako czynnik dynamizujący modele biznesowe, Wydawnictwo Politechniki Śląskiej, Katowice 2014.

17 B. Nogalski, A. Szpitter, J. Brzóska, Modele i strategie biznesu... 
Richter ${ }^{18}$ analyzed BMs in the context of the transformation of the electric power sector into a more sustainable energy production based on renewable energies. The review of the BM showed the existence of two basic choices: utility-side BMs and customer-side BMs. Another author focused on the identification and classification of new business opportunities emerging from the coevolution of the energy and digital transitions ${ }^{19}$. Potential BMs that enhance the value of PV to key stakeholders and, thus, increase market penetration (e.g., by incorporating energy storage, controls, and other technologies which allow the system to be independently controlled and dispatched) have been reported by Frantzis et al. ${ }^{20}$ Burger and Luke 21 presented empirical analysis of the most common BMs for the deployment of demand response and energy management systems, electricity and thermal storage, and solar PV distributed energy resources. They classified revenue streams, customer segments, electricity services provided, and resources for over a hundred BMs.

In the worldwide literature, analysis of the impact of regulations on the emergence of new BMs can be found. Using the example of the German Energiewende, Schmid et al. ${ }^{22}$ point out that the specific design of the regulatory framework determines which technologies are viable for business cases and that future developments will be shaped by policies. Analyzing specific cases, Jacobsson and Lauber ${ }^{23}$ discuss regulation-enabled wind turbine and solar BMs in Germany. Hillenbrand et al. ${ }^{24}$ emphasize that the profitability of BMs based on self-consumption (presumption models) depends on the design of the regulation, and Losneret al. ${ }^{25}$ assess the impact of regulation on virtual power plant BMs.

18 M. Richter, Utilities' business models for renewable energy: A review, "Renewable and Sustainable Energy Reviews" 2012, no. 16, pp. 2483-2493.

19 E. Facchinetti, Eleven business opportunities emerging from the energy transition, "Network Industries Quarterly" 2018, no. 20, pp. 21-27.

20 L. Frantzis et al., Photovoltaic Business Models, NREL, 2009, http://www.nrel.gov/docs/fy08 osti/42304.pdf (accessed: 4.01.2020).

21 S.P. Burger, M. Luke, Business models for distributed energy resources: A review and empirical analysis, "Energy Policy" 2017, no. 109, pp. 230-248.

22 E. Schmid, B. Knopf, A. Pechan, Putting an energy system transformation into practice: The case of the German Energiewende, "Energy Research and Social Science" 2016, no. 11, pp. 263-275.

23 S. Jacobsson, V. Lauber, The politics and policy of energy system transformation - Explaining the German diffusion of renewable energy technology, "Energy Policy" 2006, no. 34, pp. 256-276.

24 See in R. Leisen, B. Steffen, C. Weber, Regulatory risk and the resilience of new sustainable business models in the energy sector, "Journal of Cleaner Production" 2019, no. 219, pp. 865-878.

25 M. Losner, D. Bottger, T. Bruckner, Economic assessment of virtual power plants in the German energy market - A scenario-based and model-supported analysis, "Energy Economics" 2017, no. 62, pp. 125-138. 
BMs in the Polish energy sector were analyzed by Nogalski, Szpitter, and Brzóska ${ }^{26}$. They focus their interest on large-scale corporate energy companies and distributed energy resources. Their analysis included BMs in energy distribution for the following companies: RWE AG, Vattenfall AB, PGE S.A., Tauron Polska Energia S.A., Energa S.A., Enea S.A., and BMs in distributed energy: household photovoltaic installations, local biogas plants, low energy office buildings (passive). Generally, they identified (1) large-scale energy companies BMs, and (2) prosumer (distributed energy sources) BMs (e.g., a community's biogas plant). RopuszyńskaSurma and Węglarz ${ }^{27}$ proposed a new BM for a Virtual Power Plant under Polish conditions from the perspective of energy companies, which are the owners of all the infrastructure. An interesting classification of BMs for the integrated energy market is given by Matusiak ${ }^{28}$, who identified five BMs:

- Prosumer;

- ESCO (Energy Saving Company);

- Market aggregator;

- Electric car user;

- Generator (mainly using renewable energy sources).

The Polish authors highlight the significant role of Polish legislation as a factor influencing and creating BMs in our country.

\section{The research methodology}

\section{The survey}

In order to investigate micro and small enterprises operating in the energy sector, we designed a questionnaire with 35 questions divided into 4 parts. Part A is related to the enterprise's variables such as type of activity, number of employees, and belonging to a cooperation network. Part B is related to elements of business models, part $\mathrm{C}$ is related to network relations and connections, and part $\mathrm{D}$ is related to the enterprise's innovation. The authors used categorical questions, openended questions, multiple-choice questions and questions using 4-, 5- and 6-point Likert scales. The survey was addressed to enterprises belonging to the Lower Silesia Renewable Energy Cluster and enterprises located in technological parks.

26 B. Nogalski, A. Szpitter, J. Brzóska, Modele i strategie biznesu...

27 E. Ropuszyńska-Surma, M. Węglarz, A virtual power plant...

28 B.E. Matusiak, Modele biznesowe na nowym, zintegrowanym rynku energii, Wydawnictwo Uniwersytetu Łódzkiego, Łódź 2013, p. 120. 
Altogether, thirty surveys were returned. All the respondents answered the questions in parts A and B, and most of them (29) answered the questions in part C, but only some of them (17) answered the questions in part D. Only energy sector enterprises were selected for further study, which resulted in a mere 15 surveys for analysis.

The major problem ensuing from this was that the results cannot form the basis for statistical analysis, because for most of the variables, the number of observations is insignificant. Therefore, the results cannot be generalized for all micro- and small energy enterprises. They are, however, treated as an introduction to further research.

\section{Business Model Canvas}

To describe the BM, a scheme called the Business Model Canvas, which describes the essential elements of the model and the relations between them, was used. The $\mathrm{BM}$ consists of nine elements: customer segments, value proposition, channels, customer relationships, revenue streams, key resources, key activities, key partners and cost structure. The core of the BM is value proposition because the consumers and other stockholders pay for it. They do not pay only for the key product, but for other added value e.g., product performance, cleaner air, services, brand and prestige, design, product availability or convenience of use. Every BM should ensure revenue. Then the customer segments, customer relations and distribution channels are described. These allow different activities addressed to customers to be planned. The business can create and provide value only if it possesses or has relatively cheap access to resources (technology, capital, human, natural, knowledge) and cooperates with other entities (business partners).

\section{Identification of a new BM in the energy sector - survey results}

\section{Business Model Canvas - customer-side BM}

The review of the BM literature showed that BMs are divided into two types: utility-side BMs and customer-side BMs. The former is based on a small number of large projects, while the latter is based on a large number of small projects. We focused on customer-side BMs among micro and small enterprises because they are at an initial stage of development. 
According to the categorical questions, the enterprises can be divided into three categories, which are the customer segments households (46.7\%), industrials (40\%), and services (13.3\%). For the enterprises in the study, the major value proposition for their customers is satisfaction with the quality of product/service (60\%) and cost reduction (53.3\%). Less important value propositions for them are price (40\%), risk reduction (33.3\%), performance, customization, accessibility, and convenience/ usability (26.7\%), newness (20\%), brand/status (6.7\%).

The most popular customer channel among the sample is direct sale by the sales force (86.7\%). Less frequently used channels are direct sale by web sales (33.3\%), indirect sale via a wholesaler (20\%) and indirect sale via partner stores (13.3\%). The most common way of maintaining a relationship with the customers is personal assistance and dedicated personal assistance (both $60 \%$ ). Only $20 \%$ of the enterprises indicated co-creation, which means engaging the customers in assisting in the design of products. Single enterprises indicated on-line user communities and automated services.

Almost all the respondents indicated that they obtain revenue mainly from selling a product or service (93.3\%). A single enterprise pointed to brokerage fees as the main revenue stream. Among the resources allowing the enterprise to create and offer a value proposition, the respondents selected human resources (66.7\%), and intellectual resources (60\%). Less important are physical assets (26.7\%) and financial assets (12.3\%). As the most important activities a firm must undertake to operate successfully, the respondents pointed to making and delivering the product and problem solving (both 60\%). The enterprises also indicated designing the product (33.3\%) and a platform or network related to key activities (6.7\%).

Considering the network of suppliers and partners that make the business model work, the majority of respondents pointed to buyer-supplier relationships to assure reliable supplies (86.7\%). A less important type of partnership is strategic alliances between non-competitors (20\%) and strategic partnerships between competitors (13.3\%).

In terms of cost structure, here the respondents ranked six types of costs from the most important to the least. The word importance means their share of total costs. These six types of separated cost were (1) costs of system maintenance, (2) materials and resources costs, (3) labor costs, (4) external services costs, (5) other operational costs, (6) CAPEX (capital expenditures). For each type of cost, an average rating as a weighted average was calculated. 6 points were assigned to the type of the highest importance and 1 point signified the least important type of cost. The maximum total for each cost could equal 90 , with the minimum 15 . The sum was divided by the number of respondents. The average share of each cost in the total cost is shown in Figure 1. Additionally, the standard deviation was calculated for each cost. 


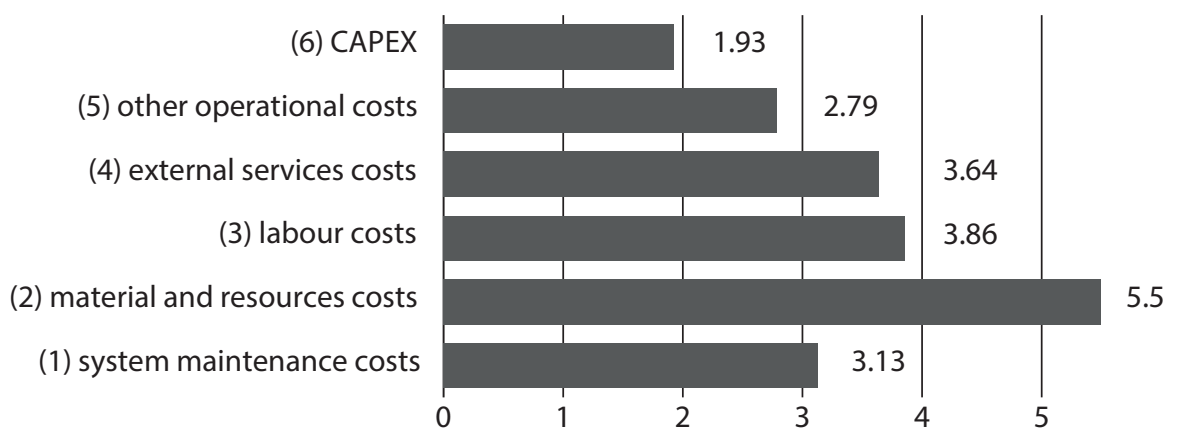

Figure 1. Average importance of each type of cost for enterprises

Source: own calculations.

The average materials and resources costs have the largest share in the total costs and the smallest standard deviation (0.9). The smallest share belongs to CAPEX with a standard deviation totaling 1.1. Labor costs have the most distributed range with a standard deviation equaling 1.55.

Five respondents from the energy sectors stated that they participate in cluster or cooperation networks with nine declaring that they do not. All the companies from the energy sector responded to the question concerning the expected benefits of cooperation networking. Those benefits are:

- new business contacts (73\% of respondents);

- joint ventures (cooperation) (66.7\%);

- access to distribution channels (46.7\%);

- consulting and marketing (26.7\%).

Here, respondents could choose the following other options: (a) competitor protection, (b) legal consultation, (c) cost reduction, (d) managerial knowledge, (e) communication skills. Only in single cases were the options mentioned above indicated.

\section{Consumer-side BM}

The data were split into three categories according to the following customer segments: households, industrials, services. The results are compared in Table 1. Due to the small numbers of consumers, two segments (industry and services) were aggregated. 
Table 1. The features of BM elements for two consumer segments

\begin{tabular}{|c|c|c|}
\hline $\begin{array}{l}\text { Customer } \\
\text { segments }\end{array}$ & Households (B2C) & Industrials \& Services (B2B) \\
\hline $\begin{array}{l}\text { Value } \\
\text { proposition }\end{array}$ & $\begin{array}{l}\text { Newness }(14.3 \%)^{a} \text { Performance } \\
(14.3 \%) \\
\text { Customization (0) } \\
\text { Satisfaction with quality (57.1\%) } \\
\text { Price }(42.9 \%) \\
\text { Cost reduction }(42.9 \%) \\
\text { Risk reduction }(14.3 \%) \\
\text { Accessibility }(28.6 \%) \\
\text { Convenience/usability (28.6\%) } \\
\text { Brand/status (14.3\%) }\end{array}$ & $\begin{array}{l}\text { Newness (25\%) } \\
\text { Performance (37.5\%) } \\
\text { Customization (50\%) } \\
\text { Satisfaction with quality (62.5\%) } \\
\text { Price (37.5\%) } \\
\text { Cost reduction (62.5\%) } \\
\text { Risk reduction (50\%) } \\
\text { Accessibility (25\%) } \\
\text { Convenience/usability (25\%) } \\
\text { Brand/status (0) }\end{array}$ \\
\hline $\begin{array}{l}\text { Customer } \\
\text { channels }\end{array}$ & $\begin{array}{l}\text { Direct sale - sales force (85.7\%) } \\
\text { Direct sale - web sales }(28.6 \%) \\
\text { Indirect sale - partner stores (14.3\%) } \\
\text { Indirect sale - wholesaler }(14.3 \%)\end{array}$ & $\begin{array}{l}\text { Direct sale - sales force (87.5\%) } \\
\text { Direct sale - web sales (37.5\%) } \\
\text { Indirect sale - partner stores }(12.5 \%) \\
\text { Indirect sale - wholesaler }(25 \%)\end{array}$ \\
\hline $\begin{array}{l}\text { Customer } \\
\text { relationship }\end{array}$ & $\begin{array}{l}\text { Personal assistance } \mathbf{( 5 7 . 1 \% )} \\
\text { Dedicated personal assistance } \\
\mathbf{( 5 7 . 1 \% )} \\
\text { Communities }(14.3 \%) \\
\text { Automated services }(0) \\
\text { Co-creation }(14.3 \%) \\
\end{array}$ & $\begin{array}{l}\text { Personal assistance }(\mathbf{6 2 . 5} \%) \\
\text { Dedicated personal assistance } \\
\mathbf{( 6 2 . 5 \% )} \\
\text { Communities }(0) \\
\text { Automated services }(12.5 \%) \\
\text { Co-creation }(25 \%)\end{array}$ \\
\hline Key activities & $\begin{array}{l}\text { Designing }(14.3 \%) \\
\text { Making and delivering the product } \\
\mathbf{( 7 1 . 2 \% )} \\
\text { Problem solving }(57.1 \%) \\
\text { Platform/network }(14.3 \%) \\
\end{array}$ & $\begin{array}{l}\text { Designing (50\%) } \\
\text { Making and delivering the product } \\
\text { (50\%) } \\
\text { Problem solving (62.5\%) } \\
\text { Platform/network (0) }\end{array}$ \\
\hline Key resources & $\begin{array}{l}\text { Physical assets }(28.6 \%) \\
\text { Intellectual resources }(42.9 \%) \\
\text { Human resources }(\mathbf{5 7 . 1} \%) \\
\text { Financial assets }(28.6 \%) \\
\end{array}$ & $\begin{array}{l}\text { Physical assets }(25 \%) \\
\text { Intellectual resources }(\mathbf{7 5 \%}) \\
\text { Human resources }(\mathbf{7 5} \%) \\
\text { Financial assets }(0)\end{array}$ \\
\hline $\begin{array}{l}\text { Types } \\
\text { of partnership }\end{array}$ & $\begin{array}{l}\text { Strategic alliances between non- } \\
\text { competitors }(28.6 \%) \\
\text { Coopetition: strategic partnerships } \\
\text { between competitors (14.3\%) } \\
\text { Buyer-supplier relationships } \\
\text { to assure reliable supplies (85.7\%) }\end{array}$ & $\begin{array}{l}\text { Strategic alliances between non- } \\
\text { competitors }(12.5 \%) \\
\text { Coopetition: strategic partnerships } \\
\text { between competitors (12.5\%) } \\
\text { Buyer-supplier relationships } \\
\text { to assure reliable supplies (87.5\%) }\end{array}$ \\
\hline $\begin{array}{l}\text { Cost structure } \\
(X, Y) \\
\text { where: } \\
X \text { - average } \\
\text { weighted costs } \\
Y \text { - standard } \\
\text { deviation }\end{array}$ & $\begin{array}{l}\text { Cost of system maintenance }(4.00, \\
1.20) \\
\text { Materials and resources costs }(5.43, \\
1.05) \\
\text { Labor costs }(4.29,1.39) \\
\text { External services costs }(3.57,1.18) \\
\text { Other operational costs }(2.43,0.73) \\
\text { CAPEX }(1.29,0.70)\end{array}$ & $\begin{array}{l}\text { Cost of system maintenance }(2.38, \\
1.32) \\
\text { Materials and resources costs }(5.57, \\
0.73) \\
\text { Labor costs }(3.43,1.59) \\
\text { External services costs }(3.71,1.28) \\
\text { Other operational costs }(3.14,1.55) \\
\text { CAPEX }(2.57,1.05)\end{array}$ \\
\hline
\end{tabular}

a The values in brackets show the percentage number of respondents who selected this option.

Source: own calculation. 


\section{Results of research}

Although the sample was small and unrepresentative, a difference in the BM can be observed if the energy companies are divided according to key consumers. Two consumer segments were specified: households (B2C), industrial and services (B2B). Both of them deliver satisfaction with quality as a proposal of value, but the companies focused on $\mathrm{B} 2 \mathrm{~B}$ consumers also deliver cost reduction as value proposition. A less important value proposition in both segments is brand. In both segments, direct sale via sales forces is the most popular customer channel in the $\mathrm{BM}$. Web sales is ranked second, but this kind of customer channel is more popular in B2B segments than in B2C.

Taking into consideration the customer relationship in the $\mathrm{BM}$, personal assistance and dedicated personal assistance are indicated most frequently in both segments. A completely different situation is related to key activities in both segments, because making and delivering products are the most important activities in $\mathrm{B} 2 \mathrm{C}$ segments, whereas in the $\mathrm{B} 2 \mathrm{~B}$ segments it is problem solving. Human resources are the most significant key sources in both segments, but, additionally, intellectual resources are important only in the B2B segments. The buyer-supplier relationships to assure reliable supplies are the most important kind of partnership in both segments. However, while the materials and resources costs have the greatest share of total costs in both segments, it does not seem surprising that the share of costs is different in both segments. In the $\mathrm{B} 2 \mathrm{C}$ segment, the subsequent costs are labor costs, costs of system maintenance, external services costs and other operational costs. While in the B2B segment external services costs are ranked second, and the next are labor costs, other operational costs, and system maintenance costs. For both segments, CAPEX is the smallest part of total costs.

It came as a surprise to learn that the energy companies indicated that new business contacts and joint ventures are the most highly expected benefits to come from cooperation networks. Conclusions

In the paper, the authors focused on customer-side BMs among micro and small enterprises. The majority of the respondents operating in the energy sector are not innovation enterprises; only $33.3 \%$ of them create or deploy innovations. Therefore, the results are unsurprising. The authors obtained the classical business model where (1) the value proposition is satisfaction with quality, price, cost and risk reduction; (2) the revenue stream is selling a product or service; (3) the communication channel with customers is direct sale by sales force; (4) the method for maintaining their customer relationships is personal assistance and dedicated personal assistance; (5) the most important aspects are human and intellectual resources; (6) the key activities are making and delivering the product and problem solving; (7) the key type of partnership is the buyer-supplier relationship to ensure reliable supplies. 
The authors indicated certain differences between two BMs for two customer segments. In the case of the value proposition, the BM for B2B consumers, unlike $\mathrm{B} 2 \mathrm{C}$ consumers, focused on cost and risk reduction, and customization. In the case of key resources, the $\mathrm{BM}$ for $\mathrm{B} 2 \mathrm{~B}$ consumers, in contrast to $\mathrm{B} 2 \mathrm{C}$ consumers, is based on intellectual resources. The most important activity in the BM for B2C consumers is making and delivering the products - in contrast to the BM for the B2B segments, where it is problem solving.

An interesting result was that human resources are perceived as significant despite the share of labor costs being at a medium level. In the case of costs, CAPEX has the smallest share of total costs, which could be related to the low level of innovation among the respondents.

The greatest problem was the small sample size for the majority of the variables. The insignificant number of observations resulted in a lack of statistical analysis. The analysis here should be seen as an introduction to further research. The authors are aware that the research will have to be repeated in a more extensive form, and suggest that the survey should be conducted by means of direct interviews. This work will be continued.

\section{References}

Afuah A., Tucci C.L., Internet Business Models and Strategies, McGraw-Hill/Irwin, New York 2003.

Amit R., Zott C., Value creation in E-business, "Strategic Management Journal" 2001, vol. 22(6/7), pp. 493-520.

Baden-Fuller C., Haefliger S., Business Models and Technological Innovation, "Long Range Planning" 2013, vol. 46(6), pp. 419-426.

Bocken N.M.P., Short S.W., Rana P., Evans S., A literature and practice review to develop sustainable business model archetypes, "Journal of Cleaner Production" 2014, no. 65, pp. 42-56.

Brzóska J., Innowacje jako czynnik dynamizujący modele biznesowe, Wydawnictwo Politechniki Śląskiej, Katowice 2014.

Burger S.P., Luke M., Business models for distributed energy resources: A review and empirical analysis, "Energy Policy" 2017, no. 109, pp. 230-248.

Chesbrough H., Rosenbloom R.S., The role of the business model in capturing value from innovation: evidence from Xerox Corporation's technology spin-off companies, "Industrial and Corporate Change" 2002, vol. 11(3), pp. 529-555.

Facchinetti E., Eleven business opportunities emerging from the energy transition, "Network Industries Quarterly" 2018, no. 20, pp. 21-27.

Frantzis L., Graham S., Katofsky R., Sawyer H., Photovoltaic Business Models, NREL, 2009, http:// www.nrel.gov/docs/fy08osti/42304.pdf (accessed: 4.01.2020).

Hamel G., Leading the Revolution, Harvard Business School Press, Boston 2000.

IEA, Digitalisation and Energy, IEA, Paris 2017, https://www.iea.org/reports/digitalisation-and -energy (dostęp: 4.09.2020).

Jacobsson S., Lauber V., The politics and policy of energy system transformation - Explaining the German diffusion of renewable energy technology, "Energy Policy" 2006, no. 34, pp. 256-276. 
Leisen R., Steffen B., Weber C., Regulatory risk and the resilience of new sustainable business models in the energy sector, "Journal of Cleaner Production" 2019, no. 219, pp. 865-878.

Losner M., Bottger D., Bruckner T., Economic assessment of virtual power plants in the German energy market - A scenario-based and model-supported analysis, "Energy Economics" 2017, no. 62, pp. $125-138$.

Magretta J., Why business models matter, "Harvard Business Review" 2002, vol. 80(5), pp. 86-92.

Matusiak B.E., Modele biznesowe na nowym, zintegrowanym rynku energii, Wydawnictwo Uniwersytetu Łódzkiego, Łódź 2013.

Nogalski B., Szpitter A., Brzóska J., Modele i strategie biznesu w obszarze dystrybucji energii elektrycznej w Polsce, Wydawnictwo Uniwersytetu Gdańskiego, Gdańsk 2017.

Osterwalder A., Pigneur Y., Business Model Generation, Wiley \& Sons, New Jersey 2010.

Richter M., Business model innovation for sustainable energy: German utilities and renewable energy, "Energy Policy" 2013, no. 62, pp. 1226-1237.

Richter M., Utilities' business models for renewable energy: A review, "Renewable and Sustainable Energy Reviews" 2012, no. 16, pp. 2483-2493.

Ropuszyńska-Surma E., Węglarz M., A virtual power plant as a cooperation network, "Marketing and Management of Innovations" 2018, no. 4, pp. 136-149.

Schmid E., Knopf B., Pechan A., Putting an energy system transformation into practice: The case of the German Energiewende, "Energy Research and Social Science" 2016, no. 11, pp. 263-275.

Shafer S.M., Smith H.J., Linder J., The power of business models, "Business Horizons" 2005, vol. 48(3), pp. 199-207.

Teece D.J., Business models, business strategy and innovation, "Long Range Planning" 2010, no. 43, pp. 172-194.

Timmers P., Business models for electronic markets, "Electronic Markets" 1998, vol. 8, no. 2, pp. 3-8.

Weill P., Vitale M.R., Place to Space - Migrating to e-Business Models, Harvard Business School Publishing Corporation, Boston 2001.

Wirtz B.W., Pistoia A., Ullrich S., Gottel V., Business Models: Origin, Development and Future Research Perspectives, "Long Range Planning” 2016, no. 49, pp. 36-54.

\section{Abstract}

The initial identification of new business models in micro- and medium-sized energy enterprises is the aim of this paper. Based on the literature review, different definitions of business models were presented and a range of research conducted by other authors focusing on the business models in the energy sector was shortly described. The state of the art allows to identify a research gap suggesting that this type of companies has not yet been studied. Presented results of the research were addressed to micro- and medium-sized energy enterprises producing or delivering services connected with e.g. energy efficiency. The research was conducted with the use of a direct questionnaire on 30 respondents in November 2019. It was identified that the business models of these enterprises are classical. Two types of models were distinguished i.e. for companies whose key customers are households (B2C model) and business (B2B model).

Keywords: business model, new business model, business model canvas, energy sector 